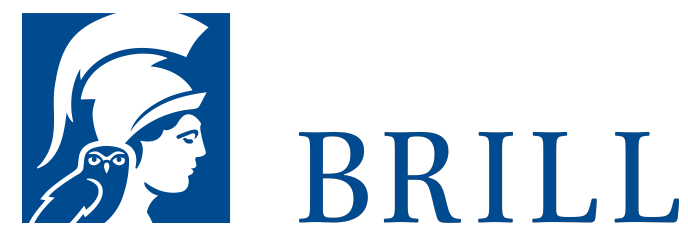

\title{
Die Poetik des Musikalischen in der Prosaliteratur um 1800
}

Eine Darstellung anhand des Musikermotivs

\section{Author: Barbara Eschlberger}

In der Zeitschrift Athenäum konstatiert Friedrich Schlegel im Jahr 1798: „Die Musik ist eigentl[ich] die Kunst dieses Jahrhunderts". In den Jahrzehnten um das Jahr 180o herum kommt es in der Geschichte der Ästhetik zu einer historischen Wende - nicht ohne den Beitrag der erzählenden Literatur, die sich eingehend den Wirkungsweisen und Eigenschaften der Musik widmet und ihr dadurch zum Rang der höchsten aller Künste verhilft. Doch können die GeSetze, die sich die Literatur selbst gibt, von diesem Diskurs unberührt bleiben? Tatsächlich steht die Beschäftigung der Dichter mit dem Thema Musik auch in Verbindung mit der Suche nach einer neuen Poetik, einer Poetik des Musikalischen. Gerade an der Behandlung des Musikermotivs kann abgelesen werden, inwieweit sich die ästhetische Neuausrichtung auch in der Entwicklung neuer narratologischer Verfahren niederschlägt und die junge Gattung des Romans selbst in Zeiten einer Sprachkrise kunstvolle Blüten treibt. Als Beispieltexte stehen Erzähltexte von Ludwig Tieck, E.T.A. Hoffmann und Jean Paul im Zentrum der Untersuchung.

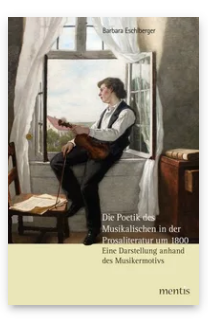

Pages: 388

Seiten

Language:

German

Subjects:

German,

Literature and

Cultural Studies

Publisher: Brill | mentis

E-Book (PDF)

Released online: o1 Mar 2014

ISBN: 978-3-

89785-964-7

List price

Paperback

Publication date: o1 Mar 2014

ISBN: 978-3-

89785-798-8

List price 
For more information see brill.com

Order information: Order online at brill.com +44330 333 0049 | customerservices@brill.com Submission information: brill.com/authors

Titles published by Brill | Fink, Brill | mentis or Brill | Schöningh: +49(o)715413279216| brill@brocom.de 